\title{
Investigating Customer Resistance to Change in Transaction Relationship with an Internet Vendor
}

\author{
Hee-Woong Kim \\ Yonsei University \\ Sumeet Gupta \\ Shri Shankaracarya Institute of Technology and Management
}

\begin{abstract}
Many academics and practitioners have reiterated the importance of online customer retention to ensure long-term profitability. Consequently, a number of studies have identified various means of customer retention. These studies lay significant emphasis on creating customer loyalty. However, retaining customers, especially in the context of Internet shopping, is very difficult because of the low costs in comparison and switching. Most of the loyalty programs have also shown disappointing results. This study suggests that by tapping on an individual customer's inclination to resist changes in a transaction relationship, an Internet vendor can achieve customer retention. Using status quo bias theory, this study examines customer resistance to change (CRC) as a means of retaining customers in a transaction relationship with the Internet vendor. The empirical study of an Internet bookstore reveals that trust, relative attractiveness, and switching costs together influence CRC. The empirical results also show that CRC and switching costs have positive effects on willingness to pay more. Implications for theory and practice are discussed. (C) 2012 Wiley Periodicals, Inc.
\end{abstract}

A number of academics (e.g., Cyer, 2008; Dowling \& Uncles, 1997; Mithas, Ramasubbu, Krishnan, \& Fornell, 2007; Reichheld \& Schefter, 2000) and practitioners have reiterated the importance of retaining customers. Reichheld and Schefter (2000) found that increasing customer retention rates by $5 \%$ increases the profits by $25 \%$ to $95 \%$ as the cost of acquiring a customer is five times as high as the cost of retaining customer (Reichheld \& Sasser, 1990). The importance of retaining customers increases particularly in e-commerce because of the low costs in comparison and switching (Chen \& Hitt, 2002). Many online vendors have therefore implemented various loyalty strategies (i.e., value-added services and loyalty points) to retain their customers.

However, Dowling and Uncles (1997) reveal that the degree of customer loyalty online is very low. Only about $10 \%$ of buyers are $100 \%$ loyal to a particular brand (Dowling \& Uncles, 1997). In online grocery, for instance, $75 \%$ of customers are relationship-averse bargain hunters (Reichheld \& Schefter, 2000). It has been observed that over $50 \%$ of customers stop visiting a website completely before their third anniversary of using the website (Reichheld \& Schefter, 2000). It is difficult for an Internet vendor to achieve loyalty from its customers because it requires customers to develop emotional attachment to the vendor. Therefore, it is necessary that online vendors look for other means to retain customers.

Online customer retention, which reflects an Internet vendor's viewpoint, implies that customers maintain transaction relationships with the vendor. If an Internet vendor can tap on customers' characteristics that incline them toward resisting changes in transaction relationship, the vendor could retain its customers. Oreg (2003) describes an individual's dispositional inclination to resist changes as resistance to change. Clearly, if an Internet vendor can identify factors which increase customer resistance to change (CRC), it can plan strategies to increase this resistance to change and thus retain its customers. A few studies (Dick \& Basu, 1994; Kyle, Graefe, Manning, \& Bacon, 2004; Pritchard, Havitz, \& Howard, 1999; Taylor \& Hunter, 2003) discuss the relationship between loyalty and CRC. Few empirical studies, however, discuss how to increase CRC by identifying its antecedents and how to use CRC as a means of retaining customers. Furthermore, literature lacks theoretical foundations that explain CRC (Lapointe \& Rivard, 2005).

Therefore, the objective of this study is to examine online customer retention in terms of CRC in transaction relationship with an Internet vendor. The consequence of achieving CRC in transaction relationship 
with a vendor is that the vendor can enjoy price premium (i.e., customer's willingness to pay more) through customer's attachment to the vendor (Ganesh, Arnold, \& Reynolds, 2000; Srinivasan, Anderson, \& Ponnavolu, 2002). Specifically, this study seeks to answer the following questions: (1) what are the antecedents of CRC in transaction relationship with an online vendor? and (2) how CRC can influence an individual customer's willingness to pay more? This study uses status quo bias theory (Samuelson \& Zeckhauser, 1988) to conceptualize CRC in online context. This study intends to contribute to the electronic commerce literature by advancing the theoretical understanding of CRC for online customer retention. It also aims to offer practical suggestions to Internet vendors for increasing customer retention.

The paper is organized as follows. In the next section, literature review on CRC and status quo bias theory is discussed. This is followed by research model and hypothesis. Then research methodology and data analysis and results are presented. In the last two sections, findings and limitations of this study as well as the implications of the findings to theory and practice are discussed.

\section{CONCEPTUAL AND THEORETICAL BACKGROUND}

\section{CRC and Status Quo Bias Theory}

Resistance to change is defined as an individual's tendency to resist or avoid making changes, to devalue change generally, and to be averse to change across diverse contexts and types of change (Oreg, 2003). Resistance to change has also been conceptualized as any conduct that seeks to keep the status quo, or the persistence to avoid change (De Val \& Fuentes, 2003). Following Oreg (2003), this study defines CRC as an individual customer's tendency to resist or avoid switching from current vendor to another vendor for transactions.

This study adopts status quo bias theory in explaining CRC. As De Val and Fuentes (2003) conceptualize resistance to change in terms of status quo, status quo bias theory is suitable as the theoretical foundation for explaining CRC. Status quo bias theory explains the causes of people's preference for the status quo (i.e., maintaining one's current situation or previous decision) (Samuelson \& Zeckhauser, 1988). In a transaction relationship with a vendor, customers also may have a status quo alternative, i.e., maintaining the transaction relationship with the current vendor. Status quo bias theory can thus form the theoretical foundation for a model of CRC in transaction relationships with a vendor.

Samuelson and Zeckhauser (1988) explain status quo bias in terms of rational decision making, cognitive misperceptions, and psychological commitment. In rational decision making, rationality requires customers to choose alternatives based on their rational assessment. Three main factors contribute to status quo bias in terms of rational decision making: comparison with alternatives, transition costs, and uncertainty and risk (Samuelson \& Zeckhauser, 1988). First, rationality requires customers to compare alternatives across Internet vendors (i.e., comparison with alternatives). Online customers can easily compare alternatives because of low search costs. If there were no better alternative than the current vendor, the comparison results would require rational customers to maintain status quo and thus maintain the transaction relationship with the current vendor. Second, transition from the status quo to an alternative may require additional monetary and nonmonetary costs. Such transition costs would result in a customer preferring to stay with the status quo option rather than making a switch, leading to status quo bias. Third, uncertainty costs associated with the new alternative can also result in status quo bias. People experience negative psychological reactions to uncertainty associated with the new situation, which biases them toward the status quo.

The cognitive misperception of loss aversion also explains status quo bias (Samuelson \& Zeckhauser, 1988). Loss aversion is a psychological principle that has been observed in human decision making (Kahneman, Knetsch, \& Thaler, 1991), according to which losses loom larger than gains. In other words, individuals have strong preference for avoiding losses than acquiring gains.

The next category of status quo bias is explained on the basis of psychological commitment. Three main factors contribute to psychological commitment: sunk costs, regret avoidance, and efforts to feel in control (Samuelson \& Zeckhauser, 1988). First, sunk costs refer to previous commitments, which cause reluctance to switch to a new alternative. People tend to cut their losses by maintaining their status quo choices if there are sunk costs and investments in the previous decision or in a relationship with the current vendor. Second, people feel stronger regret for bad outcomes resulting from new action taken than for similar bad outcomes resulting from inaction (Samuelson \& Zeckhauser, 1988). People thus tend to avoid regrettable actions and prefer the status quo when they are satisfied with it. Third, efforts to feel in control stem from individuals' desire to direct or determine their own situations (Samuelson \& Zeckhauser, 1988). This desire can result in status quo bias because individuals do not want to lose control by switching to another uncertain transaction relationship with a new vendor.

This study identifies four factors corresponding to the causes of status quo bias (see Table 1) as the antecedents of CRC: relative attractiveness, switching costs, satisfaction, and trust. This study will discuss how the factors correspond to the causes of status quo bias and how they lead to CRC in transaction relationship with an Internet vendor through either dedicationbased relationship development or constraint-based relationship development in the following section. 
Table 1. Causes of Status Quo Bias.

\begin{tabular}{lll}
\hline \multicolumn{2}{c}{ Cause of Status Quo Bias } & \multicolumn{1}{c}{ Corresponding Factor } \\
\hline Rational decision making & Comparison with alternatives & Relative attractiveness \\
& Transition costs & Switching costs (transition costs) \\
& Uncertainty and risk & Switching costs (uncertainty costs) \\
Cognitive misperception & Loss aversion & Switching costs (loss costs) \\
Psychological commitment & Sunk costs & Switching costs (sunk costs) \\
& Regret avoidance & Satisfaction \\
& Control & Trust \\
\hline
\end{tabular}

\section{CRC and Other Similar Constructs}

There are several constructs (e.g., commitment and loyalty) that are similar to CRC. Therefore, it is essential to distinguish CRC from these similar constructs. The differences among them can be explained by customers' motivation for maintaining relationship with an Internet vendor. Bendapudi and Berry (1997) explain that customers maintain relationship with a service provider either because of constraint (i.e., "have to" stay in the relationship) or because of dedication (i.e., "want to" stay in the relationship). While customers in constraint-based relationships preserve the relationships because of exit costs, customers in dedicationbased relationships desire continuance. Internet vendors could foster CRC by putting efforts for dedicationbased relationship development and constraint-based relationship development.

Commitment, which is defined as an enduring desire to maintain a relationship (Morgan \& Hunt, 1994), would represent relationship maintenance resulting from dedication-based relationship development. However, CRC may result either from dedication-based or from constraint-based relationship. Although committed customers should be resistant to change in a transaction relationship with the focal vendor, customers with CRC need not necessarily be committed customers (i.e., maintaining dedication-based relationships with the vendor). Some customers could have CRC in the transaction relationship because of several constraints.

Previous studies (e.g., Anderson \& Srinivasan, 2003; Dick \& Basu, 1994; Srinivasan, Anderson, \& Ponnavolu, 2002) consider customer loyalty as having both a behavioral aspect (e.g., "repeat purchase") and a psychological aspect (e.g., "favorable attitude" and "a deeply held commitment") because loyalty with only a behavioral aspect could be spurious. This is the reason why many studies and firms have considered the development of customer loyalty as a means for dedicationbased relationship development to achieve customer retention. Similar to commitment, loyalty results from dedication-based relationship development. CRC, on the other hand, results from either dedication-based or constraint-based relationship development. In addition, CRC does not guarantee word-of-mouth promotion and willingness to pay more, whereas loyalty leads to these beneficial consequences (Dick \& Basu, 1994; Srinivasan, Anderson, \& Ponnavolu, 2002). It is known that resistance to change increases loyalty (Pritchard,
Havitz, \& Howard, 1999). It is also known that loyalty leads to resistance to change (i.e., resistance to counter persuasion) (Dick \& Basu, 1994). While loyal customers are naturally resistant to change; it is also possible that they will be resistant to change without being loyal (Choi, Kim, Kim, \& Kim, 2006).

\section{Research Model and Hypothesis}

Based on the conceptual and theoretical background and the four identified factors corresponding to the causes of status quo bias, the research model is proposed (Figure 1). Satisfaction, trust, and relative attractiveness influence CRC through dedication-based relationship development. Switching costs influence CRC through constraint-based relationship development. As a consequence of online customer retention (i.e., CRC), this study examines individual customer's willingness to pay more and examines the effect of CRC on their willingness to pay more.

\section{Antecedents of CRC}

Following Spreng, MacKenzie, and Olshavsky (1996), customer satisfaction is defined as an affective state resulting from emotional reaction to transaction experience with an Internet vendor. Customer satisfaction is a well-known antecedent of customer loyalty (Cyer, 2008; Geyskens et al., 1999). Customers are dedicated to a relationship with the vendor when they are satisfied through dedication-based relationship development. According to the regret avoidance perspective of status quo bias theory, a customer would feel stronger regret for unexpected outcomes resulting from switching than for similar unexpected outcomes resulting from staying with the current vendor (Samuelson \& Zeckhauser, 1988). According to Lazarus (1991), depending on the feelings generated, behavioral intentions emerge to activate plans for avoiding undesirable outcomes or increasing/maintaining positive outcomes (i.e., satisfaction) (Bagozzi, 1992). Thus, an individual who perceives satisfaction with the transaction relationship with the current Internet vendor would want to maintain transaction relationship with the current vendor for avoiding regrettable outcomes.

H1: Satisfaction has a positive effect on CRC. 


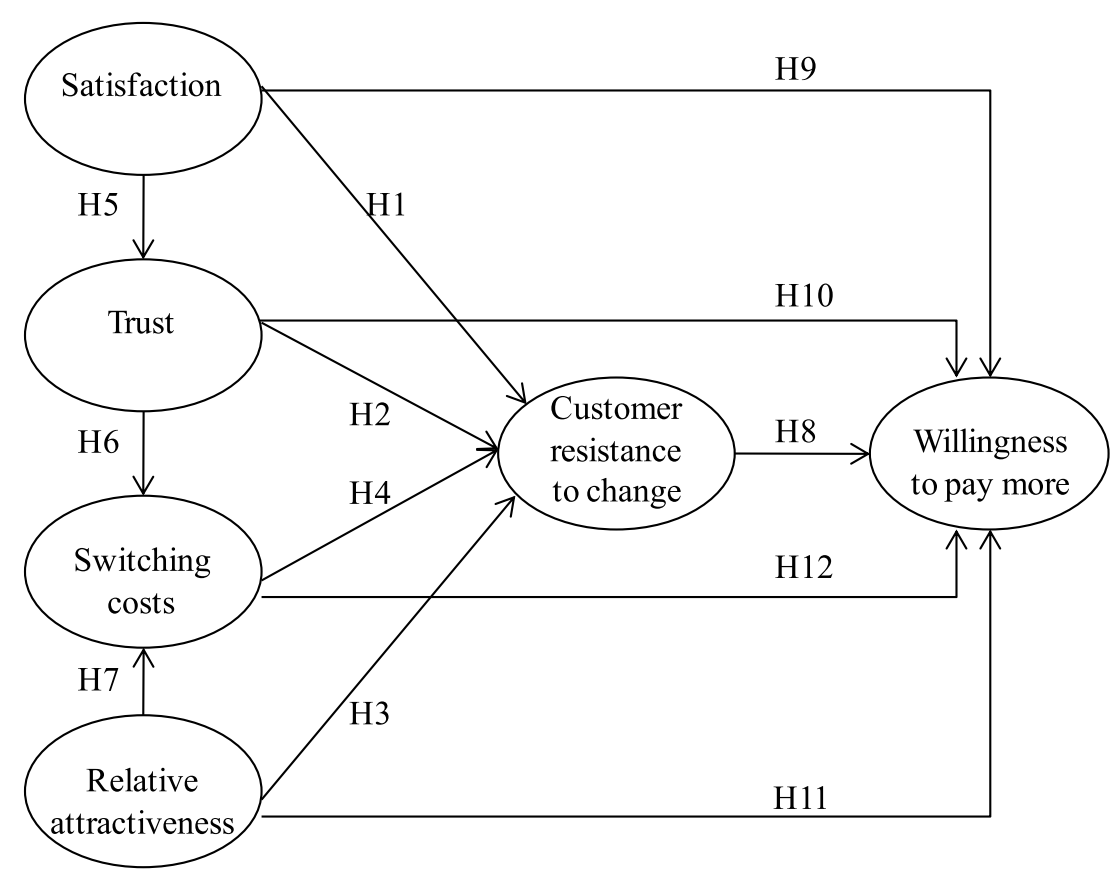

Figure 1. Research model.

From the perspective of dedication-based relationship development, an Internet vendor can also consider developing its trustworthiness (Cyer, 2008; Li \& Lee, 1994). Customers develop trust in an Internet vendor based on the perception of trustworthiness of the vendor (McKnight, Choudhury, \& Kacmar, 2002). Because Internet shopping is characterized by uncertainty and risks, trust in an Internet vendor helps customers prefer conducting transaction with the same vendor. Trust as a social phenomenon has been studied in various disciplines. Trust has been conceptualized and operationalized as a set of beliefs about the competence, benevolence, and integrity of Internet vendors (Dinev \& Hart, 2006; Gefen, 2004; Kim, Xu, \& Koh, 2004; Pavlou \& Fygenson, 2006). This study conceptualizes trust as a set of beliefs about the trustworthiness of an Internet vendor.

From the psychological commitment perspective of status quo bias, the desire to feel in control results in status quo bias (Samuelson \& Zeckhauser, 1988). Under conditions of high uncertainty and risk, online customers may place more importance on gaining control in the transaction, allowing prospects of control rather than of gains (i.e., monetary saving) to determine their behavior (Klemperer, 1995). Ajzen (2002) also explained that the behavioral intentions of people are affected by their perceived behavioral control. Perceived behavioral control refers to beliefs about the presence of internal control (e.g., personal knowledge) or external control factors (e.g., cooperation of others) that allow the behavior (Ajzen, 2002). Koller (1988) regarded trust belief as a perception of control over the exchange environment in which transactions occur. Gefen (2004) also posited that trust perception caters to the human desire to control the exchange environment. Pavlou and Fygenson (2006) further explained that trust takes a role of control belief. Since trust belief affects a customer's perception of the ability to control, a customer would desire to maintain a transaction relationship with the current vendor if (s)he trusts in the vendor. A number of studies (e.g., Chen \& Dibb, 2010; Oh et al., 2009) report that trust significantly influences customer attitude toward online purchases. Resistance to change can be considered as an attitude that signifies the resistance that a customer has toward switching from the store. Therefore, trust positively influences customer's resistance to change.

\section{H2: Trust has a positive effect on CRC.}

Again from the perspective of dedication-based relationship development, an Internet vendor can also consider enhancing its attractiveness compared to other competitors (i.e., relative attractiveness). This study defines relative attractiveness as the customer perception of the attractiveness of shopping with the current online vendor in comparison with other online vendors. Similarly, alternative attractiveness is defined as customer perceptions regarding the extent to which viable alternatives are available in the market (Jones, Mothersbaugh, \& Beatty, 2000). While relative attractiveness takes the current vendor as the reference point, alternative attractiveness takes other vendors as the reference point. When Internet transactions with a vendor are relatively more attractive than other vendors, customers may want to stay in the relationship with the vendor through dedication-based relationship development (Sung and Choi, 2010). From the rational 
decision-making perspective of status quo bias, relative attractiveness represents the comparison of current vendor with other alternative vendors. Customers would want to maintain transaction relationship with the current vendor if there were no better alternative than the current vendor (Samuelson \& Zeckhauser, 1988).

H3: Relative attractiveness has a positive effect on CRC.

From the perspective of constraint-based relationship development, Internet vendors can consider developing customer switching costs because these costs would inhibit customers from switching away to other vendors (Tsai, Huang, Jaw, \& Chen, 2006). Wang (2010) argue that under high switching costs, perceived value and corporate image have less strong influence on customer loyalty. Following Chen and Hitt (2002), this study defines switching costs as a customer's subjective perception of disutility associated with the process of switching from one vendor to another. Switching costs consist of several subtypes of switching costs such as psychological costs, procedural costs, and loss costs (Burnham, Frels, \& Mahajan, 2003; Jones, Mothersbaugh, \& Beatty, 2002). Psychological costs mean those costs involving psychological or emotional discomfort due to the switching (Burnham, Frels, \& Mahajan, 2003). Procedural costs involve the expenditure of time, effort, and economic resources incurred in switching (Burnham, Frels, \& Mahajan, 2003). Loss costs involve lost benefit costs and losses due to investments already made in the current situation (Jones, Mothersbaugh, \& Beatty, 2002).

From the rational decision-making perspective of status quo bias, transition costs correspond to the procedural switching costs (Burnham, Frels, \& Mahajan, 2003) and uncertainty costs correspond to the psychological switching costs (Burnham, Frels, \& Mahajan, 2003). From the psychological commitment perspective of status quo bias, sunk costs correspond to the loss costs (i.e., sunk costs) (Jones, Mothersbaugh, \& Beatty, 2002). From the cognitive misperception perspective, loss aversion corresponds to the loss costs (i.e., lost benefit costs) (Jones, Mothersbaugh, \& Beatty, 2002). Switching costs thus create constraints that prevent or discourage customers from switching vendors and thus increasing customers lock-in with the vendor. Bendapudi and Berry (1997) posited that switching costs motivate customers to maintain relationships (i.e., constraint-based relationships) with the current vendor. Yang and Peterson (2004) found that customer switching cost increases the resistance to change when the satisfaction and perceived value with the online vendor are above average.

H4: Switching costs have a positive effect on CRC.
According to the social exchange theory (Blau, 1964), it may be argued that trust is built when the trustee behaves in a manner that is acceptable and is in accordance with the trustor's expectations. Customers generally expect satisfaction from their transactions with a vendor, so following the social exchange theory, if the expectation is met, satisfaction can lead to trust. Previous studies (Kim, Xu, \& Koh, 2004; Lee, Kang, \& McKnight, 2007) have supported the relationship between trust and satisfaction. Trust brings comfort to the minds of customers in transactions with an Internet vendor by reducing risk and the perception of uncertainty (Cho, 2006). The psychological costs (e.g., emotional discomfort) of switching to another vendor thus increases as customers perceive trust in the current vendor. In addition, trust development requires exchanges with an Internet vendor and the relevant investment of time and effort by customers. The relevant investment of time and effort may increase switching costs, especially in terms of lost benefit costs and sunk costs (Jones, Mothersbaugh, \& Beatty, 2000). Therefore, trust in the current vendor would influence the perception of costs in switching from the current vendor. Furthermore, customers perceive relative attractiveness in Internet transactions with the current vendor when they perceive that the current vendor provides greater benefits as compared to alternative vendors. If customers switch from the current vendor to alternative vendors, they would lose the benefits they have enjoyed in Internet transactions with the current vendor. Therefore, relative attractiveness would influence switching costs in terms of loss costs.

\section{H5: Satisfaction has a positive effect on trust. \\ H6: Trust has a positive effect on switching costs. \\ H7: Relative attractiveness has a positive effect on switching costs.}

\section{Consequence of CRC}

Relationship marketing literature (Bendapudi \& Berry, 1997) explains price premium as a compensation for the investment a vendor incurs in developing and maintaining relationship with the customers. Such investments may include the costs of prospecting, identifying customer needs, modifying offerings to meet these needs, and monitoring performance. Customers who maintain (i.e., dedication based or constraint based) relationships with the vendor are willing to pay more to the vendor as a pay off for the vendor's investment in maintaining the relationship (Bendapudi \& Berry, 1997). CRC results from either dedication-based relationship development or constraint-based relationship development. Customers are willing to pay price premium when they focus on the service provided by a longassociated vendor rather than just the economics of transaction (Smith \& Brynjolfsson, 2001). Thus, those 
customers who are resistant to change in transaction relationship with a current vendor are willing to pay more to the vendor.

H8: CRC has a positive effect on the willingness to pay more.

Apart from the indirect effects of the three constructs for dedication-based relationship development on the willingness to pay more through CRC, direct effects are also expected. Lopes and Galleta (2006) found that those satisfied customers who perceive benefits in Internet transactions with a vendor are willing to pay more to the vendor. Customers are also willing to pay a premium to transact with a trustworthy Internet vendor to prevent moral hazard in case the seller has the opportunity to act opportunistically (Pavlou \& Dimoka, 2006). Customers are also willing to pay price premium to ensure that relative benefits are actually provided. Price premium acts as a risk-sharing device to allay opportunism that might increase disappointment cost (Singh \& Sirdeshmukh, 2000). Apart from the indirect effect of switching costs for constraint-based relationship development on the willingness to pay more through CRC, the direct effect is also expected. Previous studies (Lieberman \& Montgomery, 1988) support that vendor may be able to earn higher price if switching costs are sufficiently high.

H9: Satisfaction has a positive effect on the willingness to pay more.

H10: Trust has a positive effect on the willingness to pay more.

H11: Relative attractiveness has a positive effect on the willingness to pay more.

H12: Switching costs have a positive effect on the willingness to pay more.

\section{RESEARCH METHODOLOGY}

\section{Instrument Development}

This study has adopted online survey research methodology using a questionnaire. The survey instrument was developed by adopting existing validated scales wherever possible. Items for relative attractiveness were adapted from Ping (1993) to the context of this study. Similar to most previous studies, switching costs were conceptualized as a single-dimensional construct, with scales adapted from Jones, Mothersbaugh, and Beatty (2000) to reflect transition costs (SWC1), uncertainty costs (SWC2), sunk costs (SWC2), and loss costs (SWC3). Items for CRC were modified from Pritchard, Havitz, and Howard (1999). Items for willingness to pay more were adopted from Srinivasan, Anderson, and Ponnavolu (2002). Items for satisfaction were adapted from Spreng, MacKenzie, and Olshavsky (1996). Finally, items for trust were adopted items from Kim, $\mathrm{Xu}$, and Koh (2004). All items used a 7-point Likert scale ( 1 = strongly disagree, $7=$ strongly agree), except willingness to pay more which used 7-point rating scale ( $1=$ Not at all likely, $7=$ Very likely).

Two marketing scholars and three online customers reviewed the instruments to check for their face validity. Focus-group interviews with 16 people were conducted to discuss and obtain feedback about the questionnaire with regards to the clarity of the questions, the length of the instruments, the format of the scales, and the content. The final list of items is presented in Appendix.

\section{Data Collection}

This study was conducted on an Internet bookstore because books belong to the category of low-touch products (Lynch, Kent, \& Srinivasan, 2001) and vary less in quality as compared to other products. The online bookstore chosen for this study receives 120000 visits daily and sells about 15000 books daily. It is not a well-known online bookstore like Amazon.com, but a relatively small vendor. Based on the sponsorship from the marketing manager of the bookstore, data were collected for 4 days through the bookstore's website, which has a banner on its front page to publicize the survey and from that customers can click to go to the survey website.

A total of 367 valid responses were obtained from the Internet survey. Sixty-three percent of the respondents were female. The majority of respondents are 20 to 39 years of age $(76 \%)$. Most of them are students (37.3\%), working professionals $(32.8 \%)$, or housewives $(16.3 \%)$. The respondents are mostly experienced in using the Internet with $95.6 \%$ of them having 4 or more years of experience. The descriptive statistics of Respondent's data are shown in Table 2.

Nonresponse bias was assessed by comparing the sample of customers with the database of registered customers of the Internet bookstore. $t$-tests show that the sample of customers and the population of registered customers did not differ significantly in terms of age and purchase experience with the bookstore. Mann-Whitney test also did not reveal any significant

Table 2. Demographics of Respondents.

\begin{tabular}{lll}
\hline \multicolumn{2}{c}{ Demographic Variables } & \multicolumn{1}{c}{ Data } \\
\hline Age (years) & Mean (SD) & $30.1(18.0)$ \\
Gender & Female & $231(62.9 \%)$ \\
& Male & $136(37.1 \%)$ \\
$\begin{array}{l}\text { Internet usage experience } \\
\quad \text { years) }\end{array}$ & Mean (SD) & $7.8(2.6)$ \\
$\begin{array}{l}\text { Purchase experience with } \\
\quad \text { the bookstore (times) }\end{array}$ & Mean (SD) & $6.4(5.3)$ \\
Number of responses & & 367 \\
\hline
\end{tabular}


Table 3. Convergent Validity Testing.

\begin{tabular}{lccccc}
\hline Item & Standard Loading & $t$-Value & AVE & CR & $\alpha$ \\
\hline REL1 & 0.89 & 21.34 & 0.74 & 0.89 & 0.89 \\
REL2 & 0.90 & 21.43 & & & \\
REL3 & 0.79 & 17.70 & & & \\
SWC1 & 0.79 & 17.46 & 0.66 & 0.88 & 0.88 \\
SWC2 & 0.79 & 17.39 & & & \\
SWC3 & 0.86 & 20.00 & & & \\
SWC4 & 0.82 & 18.39 & & & \\
TRS1 & 0.83 & 19.10 & 0.74 & 0.89 & 0.89 \\
TRS2 & 0.85 & 19.71 & & & \\
TRS3 & 0.91 & 21.83 & & & \\
SAT1 & 0.92 & 22.99 & 0.86 & 0.94 & 0.94 \\
SAT2 & 0.95 & 24.13 & & & \\
SAT3 & 0.91 & 22.59 & & & \\
CRC1 & 0.84 & 19.30 & 0.66 & 0.85 & 0.85 \\
CRC2 & 0.84 & 19.20 & & & \\
CRC3 & 0.76 & 16.99 & & & \\
WPM1 & 0.83 & 19.26 & 0.79 & 0.92 & 0.91 \\
WPM2 & 0.95 & 23.79 & & & \\
WPM3 & 0.90 & 21.58 & & & \\
\hline
\end{tabular}

difference in gender ratio between the sample of customers and the population of registered customers.

\section{DATA ANALYSIS AND RESULTS}

\section{Instrument Validation}

The data analysis was carried out in accordance with a two-stage methodology (Anderson \& Gerbing, 1988) using LISREL. First, the covergent and discriminant validity was assessed to validate the survey instrument using confirmatory factor analysis (CFA). Convergent validity can be established by examining the standardized path loading, composite reliability (CR), Cronbach's $\alpha$, and the average variance extracted (AVE) (Gefen, Straub, \& Boudreau, 2000). The standardized path loadings were all significant $(t$-value $>1.96)$ and greater than 0.7. The CR and the Cronbach's $\alpha$ for all constructs exceeded 0.7. The AVE for each construct was greater than 0.5 . The convergent validity for the constructs was supported (Table 3).

Next, the discriminant validity of the measurement model was assessed by comparing AVE for each construct with the squared correlations between that construct and other constructs (Fornell \& Larcker, 1981). As shown in Table 4, the square root of AVE for each construct (diagonal term) exceeded the correlations between the construct and other constructs (off-diagonal terms). Hence, discriminant validity of the instrument was established.

\section{Hypotheses Testing}

After establishing the validity of the measurement model, structural model was examined using LISREL
Table 4. Correlations between Latent Constructs.

\begin{tabular}{lcccccccc}
\hline & Mean & SD & SWC & CRC & WPM & TRS & SAT & REL \\
\hline SWC & 4.27 & 1.45 & $\mathbf{0 . 8 1}$ & & & & & \\
CRC & 5.08 & 1.16 & 0.50 & $\mathbf{0 . 8 1}$ & & & & \\
WPM & 3.08 & 1.47 & 0.43 & 0.41 & $\mathbf{0 . 8 9}$ & & & \\
TRS & 5.60 & 1.05 & 0.10 & 0.53 & 0.12 & $\mathbf{0 . 8 6}$ & & \\
SAT & 5.58 & 1.17 & 0.20 & 0.45 & 0.22 & 0.63 & $\mathbf{0 . 9 3}$ & \\
REL & 5.51 & 1.05 & 0.43 & 0.62 & 0.33 & 0.32 & 0.50 & $\mathbf{0 . 8 6}$ \\
\hline
\end{tabular}

Note: The diagonal line shows the square root of AVE for each construct.

(Figure 2). The testing results suggest that the structural model adequately fits the data in comparison with the criteria suggested by Gefen, Straub, and Boudreau (2000). The normed $\chi^{2}$ is 2.28 , which is below the desired cut-off value of 3.0. Root mean square of approximation (RMSEA) is 0.059 , indicating a good fit since it is lower than 0.080, while Standardized Root Meansquare Residual (RMR) is 0.066, which is lower than the cut off value of 0.08 . The other statistics show that structural model adequately fits the data: $\mathrm{GFI}=0.92$, $\mathrm{AGFI}=0.89, \mathrm{CFI}=0.98$, and $\mathrm{NFI}=0.97$.

The results indicate that trust (H2), switching costs (H3), and relative attractiveness $(\mathrm{H} 4)$ have significant positive effects on CRC, explaining $58 \%$ of the variance. CRC (H8) and switching costs (H12) have significant positive effects on willingness to pay more, explaining $25 \%$ of the variance. Satisfaction (H5) has a significant effect on trust. Relative attractiveness (H7) has a significant effect on switching costs. However, five other hypotheses (H1, H6, H9, H10, and H11) were not supported.

\section{DISCUSSION AND IMPLICATIONS}

\section{Discussion of Findings}

The results show several interesting findings. First, from the perspective of dedication-based relationship development, trust and relative attractiveness (i.e., causes of status quo bias in terms of control and comparison with alternative, respectively) have significant effects on CRC. Morgan and Hunt (1994) found a positive relationship between trust and dedication-based relationship maintenance as confirmed in this study. However, there have been conflicting findings in previous research. Harris and Goode (2004) found that trust leads to dedication-based relationship maintenance such as loyalty and commitment. In contrast, Luarn and Lin (2003) found that trust has no significant effect on commitment in the context of online traveling and video-ondemand e-services. However, the results of this study reveal that trust in an Internet vendor increases customers' desire to maintain transaction relationships with the vendor. Regarding the significant positive effect of relative attractiveness on CRC, previous studies (Anderson \& Narus, 1990; Kelley \& Thibaut, 1978; 


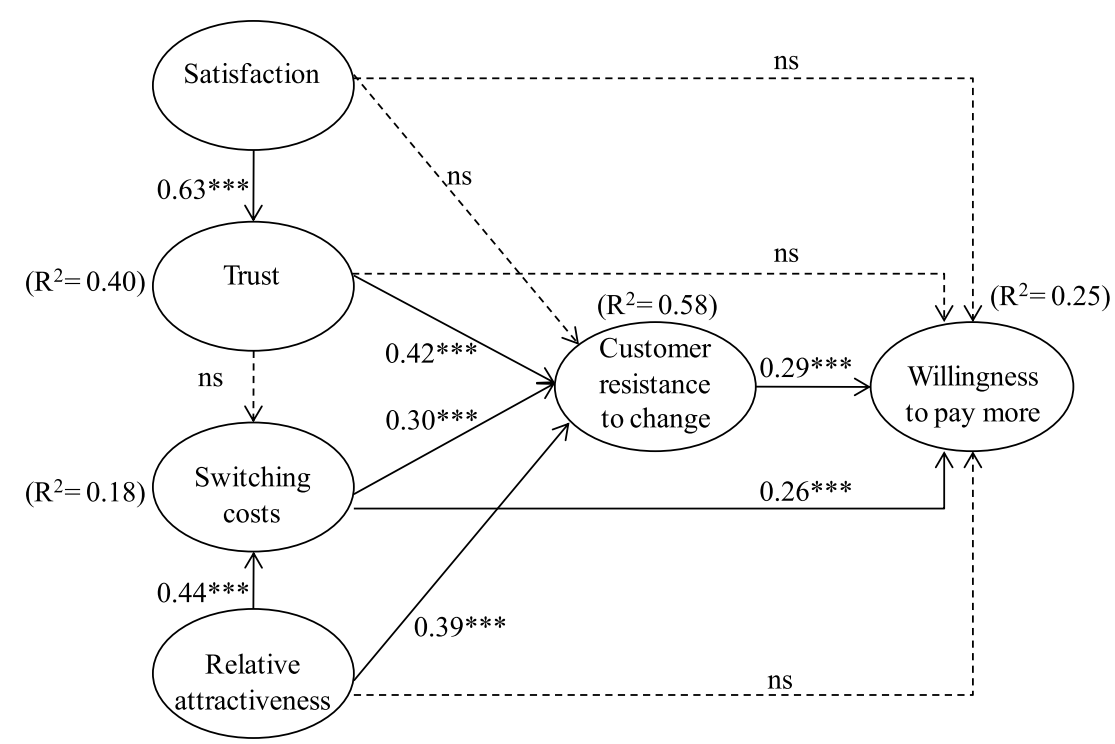

Figure 2. Model testing results.

Normed $\chi^{2}=2.28, \mathrm{RMSEA}=0.059$, GFI $=0.92$, AGFI $=0.89, \mathrm{CFI}=0.98, \mathrm{NFI}=0.97\left({ }^{* * *} p<0.001\right.$, n.s. $=$ not significant at the 0.05 level)

Sung \& Choi, 2010) explain that customers may be dependent on the vendor and stay with the vendor because the relational outcomes, though not necessarily satisfying, are still better than alternatives. Thus, relative attractiveness of Internet transaction with the vendor increases customers' desire to maintain relationships with the vendor.

Second, from the perspective of constraint-based relationship development, switching costs (i.e., causes of status quo bias in terms of transition costs, uncertainty and risk, loss aversion, and sunk costs) have a significant positive effect on CRC. Bendapudi and Berry (1997) proposed switching costs from the perspective of constraint-based relationship development. A number of studies report that switching costs prevent customers from switching vendors, even if behavioral motivation to switch exists (Singh \& Sirdeshmukh, 2000). However, switching costs in the electronic marketplace are generally known to be low, as a competing firm is "just a click away" (Friedman, 1999). This study shows that switching costs may not necessarily be so low that they fail to deter customers from switching to another vendor even in an Internet shopping context.

Third, as a consequence of online customer retention, this study shows CRC has a positive significant effect on willingness to pay more. This finding is similar to previous research (Srinivasan, Anderson, \& Ponnavolu, 2002) on relationship marketing, showing the positive effect of customer loyalty on willingness to pay more. Customer loyalty represents rather dedicationbased relationship of customer with a vendor. However, CRC results from either dedication-based relationship development or constraint-based relationship development. This study thus shows that CRC, regardless of dedication-based relationship or constraint-based relationship, has a significant impact on willingness to pay more.

Fourth, among the antecedents of CRC, switching costs have a direct significant positive effect on willingness to pay more. Consistent with the finding in this study, previous study (Leiberman \& Montgomery, 1988) have found that vendors are able to charge price premium if the switching cost is high. However, three other antecedents (trust, relative attractiveness, and satisfaction) do not have significant direct effects on willingness to pay more. This study conducted a mediation testing (Baron \& Kenney, 1986) as a post hoc analysis to find the potential reason of this nonsignificance. Table 5 shows that CRC acts as a full mediator between the three antecedents and the willingness to pay more (as the relationships between TRS, REL, SAT, and WPM do not remain significant when CRC is introduced).

The testing results in Figure 2 show that satisfaction (i.e., cause of status quo bias in terms of regret avoidance) does not have a significant effect on CRC. Another mediation test shows the effect of satisfaction on CRC is fully mediated by trust. Trust does not have a significant effect on switching costs. This could be due to the fact that trust may reduce some components of switching costs (e.g., loss costs such as benefit loss) of switching to another vendor but not other components (e.g., transition costs, sunk costs, and uncertainty costs). Hence, an overall effect may not be seen. To test this argument, a post hoc analysis was conducted by using only SWC4, which represents loss costs. The results show that trust indeed has a significant effect on this cost. 
Table 5. Mediation Testing Results.

\begin{tabular}{|c|c|c|c|c|c|c|c|c|}
\hline \multicolumn{3}{|l|}{ Trust } & \multicolumn{3}{|c|}{ Relative Attractiveness } & \multicolumn{3}{|c|}{ Satisfaction } \\
\hline $\begin{array}{l}\text { Independent } \\
\text { Variable }\end{array}$ & $\begin{array}{c}\text { Dependent } \\
\text { Variable }\end{array}$ & $\begin{array}{c}\text { Standard } \\
\text { Beta }\end{array}$ & $\begin{array}{c}\text { Independent } \\
\text { Variable }\end{array}$ & $\begin{array}{c}\text { Dependent } \\
\text { Variable }\end{array}$ & $\begin{array}{c}\text { Standard } \\
\text { Beta }\end{array}$ & $\begin{array}{c}\text { Independent } \\
\text { Variable }\end{array}$ & $\begin{array}{l}\text { Dependent } \\
\text { Variable }\end{array}$ & $\begin{array}{c}\text { Standard } \\
\text { Beta }\end{array}$ \\
\hline TRS & WPM & $0.17^{* * *}$ & REL & WPM & $0.29^{* * *}$ & SAT & WPM & $0.19^{* * *}$ \\
\hline TRS & CRC & $0.52^{* * *}$ & REL & CRC & $0.57^{* * *}$ & SAT & CRC & $0.36^{* * *}$ \\
\hline $\begin{array}{l}\text { TRS } \\
\text { CRC }\end{array}$ & WPM & $\begin{array}{r}-0.05^{\text {n.s. }} \\
0.43^{* * *}\end{array}$ & $\begin{array}{l}\text { REL } \\
\text { CRC }\end{array}$ & WPM & $\begin{array}{l}0.09^{\text {n.s. }} \\
0.34^{* * *}\end{array}$ & $\begin{array}{l}\text { SAT } \\
\text { CRC }\end{array}$ & WPM & $\begin{array}{l}0.05^{\text {n.s. }} \\
0.38^{* * *}\end{array}$ \\
\hline
\end{tabular}

n.s. $=$ not significant, ${ }^{* * *} p<0.001$

\section{Limitations and Future Research Directions}

The results of this study should be interpreted in the context of its limitations. First, the study is limited to the context of a specific Internet bookstore. It would be useful to replicate this study across other Internet vendors to establish the robustness of the model results. Second, this study conceptualizes switching costs as a single dimensional construct. However, as discussed earlier, switching costs consist of different subtypes such as uncertainty costs, transition costs, loss costs, and sunk costs. Future studies could conceptualize switching costs as a multidimensional construct to examine in-depth effects of multiple dimensions of switching costs on CRC. Third, this study discussed how the identified antecedents of CRC can be used for dedication-based relationship development and constraint-based relationship development. However, this study has not considered relevant relationship development construct. Future studies could develop and examine corresponding constructs and test their effects on CRC. Fourth, future studies could consider testing the relationship between CRC and customer loyalty within a nomological network. Fifth, the model was tested in an online context because of the high failure rate of online loyalty programs and low costs in comparison and switching online. The results of this study should be applied in offline context with caution. It is possible to conduct a study in the offline context by modifying the model of this study to include other factors (e.g., convenience) in the model. Lastly, because respondents were self-selected to participate in the survey, it seems that more committed consumers would have participated in the survey. The mean value of transaction experience with the vendor is 6.4 (standard deviation $[\mathrm{SD}]=5.3$ ). The mean value of CRC is 5.08 ( $\mathrm{SD}=1.16)$. However, this level of CRC and transaction experience would not affect the hypotheses testing results significantly.

\section{Theoretical Implications}

This study offers several implications for theory and practice. From the theoretical perspective, first, this study introduces a new construct ' $C R C$ ' in electronic commerce research. This study approaches the issue of online customer retention by introducing CRC in a transaction relationship with an Internet ven- dor, whereas pervious studies have approached it in through customer loyalty. As there are two types of relationship between a vendor and returning customers (Bendapudi \& Berry, 1997), loyalty alone cannot explain those returning customers because it mainly focuses on dedication-based relationship between the customers and the vendor. Most of the previous research on loyalty identifies the antecedents mainly from dedication-based relationship development, such as satisfaction (Cyer, 2008; Oliver, 1999), trust (Cyer, 2008; Gefen, 2003), and Web site design (Mithas et al., 2007). They have neglected constraint-based relationship development and its effect on customer retention. Customers could be resistant to change in transaction relationship because of either dedication-based relationship or constraint-based relationship. Customers would thus transact again with the same Internet vendor if they are resistant to changing their transaction relationships with the vendor, despite not having loyalty to the vendor.

Second, this study adds to literature by examining theory-driven CRC for retaining customers in the context of electronic commerce. A few studies (Dick \& Basu, 1994; Kyle et al., 2004; Pritchard, Havitz, \& Howard, 1999; Taylor \& Hunter, 2003) discuss the relationship between loyalty and CRC. However, little studies with empirical testing discuss how to increase CRC by identifying its antecedents and how to use CRC as a means for customer retention. Furthermore, literature lacks theoretical foundations that explain CRC (Lapointe \& Rivard, 2005). Based on status quo bias theory (Samuelson \& Zeckhauser, 1988), this study has identified three antecedents of CRC in transaction relationship with an Internet vendor: relative attractiveness from comparison with alternatives in rational decision making, trust from control in psychological commitment, and switching costs from cost-related causes of status quo bias over rational decision making, cognitive misperception, and psychological commitment. The first two antecedents can be used for dedication-based relationship development while the last one can be used for constraint-based relationship development.

This study further shows CRC and switching costs have positive significant effects on customer's willingness to pay more in the transaction relationship with the vendor. This is additional contribution to the electronic commerce literature as the current literature has only associated price premium with loyalty (Srinivasan, Anderson, \& Ponnavolu, 2002), reputation (Landon \& 
Smith, 1998), trust (Ba \& Pavlou, 2002), delivery speed (Li \& Lee, 1994), and convenience (Nault \& Dexter, 1995). This study shows that switching costs could generate price premium through the significant effect on willingness to pay more. The mediation effect of CRC for trust, satisfaction, and relative attractiveness to willingness to pay more also emphasizes the importance of CRC. This is, thus, one of the first known theory-driven studies of CRC in e-commerce, examining the formation of CRC and its consequence.

Another key research implication from this study is in terms of status quo bias theory. Status quo bias theory has been applied to explain human behavior and decision making in general, as well as to illuminate the broad context of customer choice. As an extension of previous research, this study has demonstrated how status quo bias theory can be applied to explain customer retention at the level of the transaction relationship with an Internet vendor. This study has also identified four directly and indirectly significant antecedents of CRC based on status quo bias theory. This study extends the application of status quo bias theory from economics and decision-making areas into the electronic commerce domain.

\section{Practical Implications}

From the practice perspective, this study shows that an Internet vendor can retain customers by instilling in them the resistance to change vendors in their online transactions. Regarding online customer retention, first, this study also affirms earlier suggestions that trust leads to dedication-based relationships (Gefen, 2003; Harris \& Goode, 2004). Hence, it is definitely worthwhile for Internet vendors to invest in efforts that can enhance their trustworthiness as perceived by customers. Examples of such efforts include publicizing customer testimonies, deploying reliable product delivery systems, offering generous product return policies, and providing good after-sales services through customer hotlines. Internet vendors can also improve their trustworthiness by enhancing their Web site designs such as navigation design, visual design, and information design (Cyer, 2008).

Second, this study suggests that Internet vendors should enhance their attractiveness, compared to other competing vendors, for online customer retention. This suggests that Internet vendors should consider comparison with other competitors in their business such as delivering relatively higher quality products and services to increase relative attractiveness.

Third, this study affirms that the role of switching costs in online customer retention cannot be underestimated, although it is known that switching costs are very low in the electronic marketplace (Friedman, 1999). There are several subtypes of switching costs such as psychological costs, procedural costs, and loss costs. Psychological costs mean those costs which involve psychological or emotional discomfort due to the switching (Burnham, Frels, \& Mahajan, 2003). Pro- cedural costs involve the expenditure of time, effort, and economic resources incurred in switching (Burnham, Frels, \& Mahajan, 2003). Loss costs involve losses due to investments already made in the status quo (Jones, Mothersbaugh, \& Beatty, 2002). While procedural switching costs (e.g., setup costs and learning costs) may be negligible in a customer's decision to switch from one vendor to another, other types of switching costs (e.g., loss costs) should not be neglected in electronic commerce. Hence, it is definitely worthwhile for an Internet vendor to invest in efforts that can increase the switching costs of its customers. Examples of such efforts include enhancing the trustworthiness of the vendor (for increasing psychological costs), providing customized services based on the analysis of individual requirements (for increasing loss costs), and enabling customers to become familiar with Internet transactions at its Web site (for increasing loss costs).

Providing loyalty points also increase customer switching costs as the customer keeps coming back to the site for using the accumulated loyalty points as a discount or reduction in price of another product from the Web site. These points bind the customer to the site and keep them coming back to the site. Vendors can also increase switching costs by quoting two prices (actual price and discounted price) for each product. These prices increase the reference prices of the customer making him perceive that they are receiving products at a lower value. Another way of increasing switching costs is to make the Web site more attractive with easy to pay and check out options. Vendors can send SMS to their customers providing list of new arrivals at the store (depending upon customer's likes), thus being first mover to attract the customer. The vendors can open a virtual community at their store front whereby they allow customers to interact with each other and obtain reviews and comments on the books of the store.

\section{CONCLUSION}

This research is among a limited few studies that attempt to explain online customer retention in terms of $\mathrm{CRC}$ in transaction relationships with an Internet vendor. If customers are resistant to change in their transaction relationships with an Internet vendor, they will return to the vendor for future transactions, despite not being loyal to the vendor. This study develops a theoretical model for CRC by bringing status quo bias theory (Samuelson \& Zeckhauser, 1988) to the forefront. This study highlights the significance of switching costs as a key determinant of CRC. It affects online customer retention though constraint-based relationship development. This study also highlights the significance of trust and relative attractiveness as additional key determinants of CRC from the dedication-based relationship development perspective. Furthermore, this study indicates that CRC and switching costs lead to customers' willingness to pay more in transactions with the vendor. This study thus contributes to the electronic 
commerce literature, especially online customer retention research, by providing explanations of the mechanism of online customer retention in terms of CRC and additional influences on customers' willingness to pay more. The findings offer Internet vendors suggestions for retaining customers and enjoying price premium through customers' willingness to pay more.

\section{References}

Ajzen, I. (2002). Perceived behavioral control, self-efficacy, locus of control, and the theory of planned behavior. Journal of Applied Social Psychology, 32, 665-683.

Anderson, A., \& Gerbing, D. W. (1988). Structural equation modeling in practice: A review and recommended two-step approach. Psychological Bulletin, 103, 324-411.

Anderson, J. C., \& Narus, J. A. (1990). A model of distributor firm and manufacturer firm working partnerships. Journal of Marketing, 54, 42-58.

Anderson, R. E., \& Srinivasan, S. S. (2003). E-satisfaction and E-loyalty: A contingency framework. Psychology and Marketing, 20, 123-138.

Ba, S., \& Pavlou, P. A. (2002). Evidence of the effect of trust building technology in electronic markets: Price premiums and buyer behavior. MIS Quarterly, 26, 243-268.

Bagozzi, R. P. (1992). The Self-regulation of attitudes, intentions, and behavior. Social Psychology Quarterly, 55, 178204.

Baron, R. M., \& Kenny, D. A. (1986). The moderator-mediator variable distinction in social psychological research: Conceptual, strategic, and statistical considerations. Journal of Personality and Social Psychology, 51, 1173-1182.

Bendapudi, N., \& Berry, L. L. (1997). Customers' motivation for maintaining relationships with service providers. Journal of Retailing, 73, 15-37.

Blau, P. M. (1964). Exchange and power in social life. New York: John Wiley.

Burnham, T. A., Frels, J. K., \& Mahajan, V. (2003). Consumer switching costs: A typology, antecedents, and consequences Journal of the Academy of Marketing Science, 31, 109-126.

Chen, J., \& Dibb, S. (2010). Consumer trust in the online retail context: Exploring the antecedents and consequences. Psychology and Marketing, 27, 323-346.

Chen, P. Y., \& Hitt, L. M. (2002). Measuring switching costs and the determinants of customer retention in internetenabled businesses: A study of the online brokerage industry. Information Systems Research, 13, 255-274.

Cho, V. (2006). A study of the roles of trusts and risks in information-oriented online legal services using an integrated model. Information and Management, 43, 502-520.

Choi, D. H., Kim, C. M., Kim, S. I., \& Kim, S. H. (2006). Customer loyalty and disloyalty in internet retail stores: Its antecedents and its effect on customer price sensitivity. International Journal of Management, 23, 925-941.

Cyer, D. (2008). Modeling web site design across cultures: Relationships to trust, satisfaction, and e-loyalty. Journal of Management Information Systems, 24, 47-72.

De Val, M. P., \& Fuentes, C. M. (2003). Resistance to change: A literature review and empirical study. Management Decision, 41, 148-155.

Dick, A. S., \& Basu, K. (1994). Customer loyalty: Toward an integrated conceptual framework. Journal of the Academy of Marketing Science, 22, 99-113.
Dinev, T., \& Hart, P. (2006). An extended privacy calculus model for e-commerce transactions. Information Systems Research, 17, 61-80.

Dowling, R., \& Uncles, M. (1997). Do customer loyalty programs really work? Sloan Management Review, 38, 71-82.

Fornell, C., \& Larcker, D. (1981). Evaluating structural equation models with unobservable variables and measurement error. Journal of Marketing Research, 18, 39-50.

Friedman, T. L. (1999). Amazon you. New York Times, A21, Feburary 26.

Ganesh, J., Arnold, M. J., \& Reynolds, K. E. (2000). Understanding the customer base of service providers: An examination of the differences between switchers and stayers. Journal of Marketing, 64, 65-87.

Gefen, D. (2003). Customer loyalty in e-commerce. Journal of the Association for Information Systems, 3, 27-51.

Gefen, D. (2004). What makes an ERP implementation relationship worthwhile: Linking trust mechanisms and ERP usefulness. Journal of Management Information Systems, $21,263-288$

Gefen, D., Straub, D. W., \& Boudreau, M. (2000). Structural equation modeling and regression: Guidelines for research practice. Communications of the Association for Information Systems, 4, 2-76.

Geyskens, I., Steenkamp, J. E. M., \& Kumar, N. (1999). A meta-analysis of satisfaction in marketing channel relationships. Journal of Marketing Research, 36, 223-238.

Harris, C. L., \& Goode M. H. M. (2004). The four levels of loyalty and the pivotal role of trust: A study of online service dynamics. Journal of Retailing, 80, 139-158.

Jones, M. A., Mothersbaugh, D. L., \& Beatty, S. E. (2000). Switching barriers and repurchase intentions in services. Journal of Retailing, 76, 259-274.

Jones, M. J., Mothersbaugh, D. L., \& Beatty, S. E. (2002). Why customers stay: Measuring the underlying dimensions of services switching costs and managing their differential strategic outcomes. Journal of Business Research, 55, 441450 .

Kahneman, D., Knetsch, J. L., \& Thaler, R. H. (1991). The endowment effect, loss aversion, and status quo bias. The Journal of Economic Perspectives, 5, 193-206.

Kelley, H. H., \& Thibaut, J. W. (1978). Interpersonal relations: A theory of interdependence. New York: John Wiley.

Kim, H. W., Xu, Y., \& Koh, J. (2004). A comparison of online trust building factors between potential and repeat customers. Journal of the Association for Information Systems, 5, 392-420.

Klemperer, P. (1995). Competition when consumers have switching costs: An overview with applications to industrial organizations, macroeconomics, and international trade. Review of Economic Studies, 62, 515-539.

Koller, M. (1988). Risk as a determinant of trust. Basic and Applied Social Psychology, 9, 265-276.

Kyle, G., Graefe, A., Manning, R., \& Bacon, J. (2004). Predictors of behavioral loyalty among hikers along the Appalachian trail. Leisure Science, 26, 99-118.

Landon, S., \& Smith, C.E. (1998). Quality expectations, reputation, and price. Southern Economic Journal, 64, 628647.

Lapointe, L., \& Rivard, S. (2005). A multiple model of resistance to information technology implementation. MIS Quarterly, 29, 461-491.

Lazarus, R.S. (1991). Emotion and adaptation. New York: Oxford University.

Lee, K. C., Kang, I., \& McKnight, D. H. (2007). Transfer from offline trust to key online perceptions: An empirical study. 
IEEE Transactions on Engineering Management, 54, 729741.

Li, L., \& Lee, Y. S. (1994). Pricing and delivery-time performance in a competitive environment. Management Science, 40, 633-646.

Lieberman, M. B., \& Montgomery, D. B. (1988). First-mover advantages. Strategic Management Journal, 9, 41-58.

Lopes, B., \& Galletta, D. F. (2006). Consumer perceptions and willingness to pay for intrinsically motivated online content. Journal of Management Information Systems, 23, 203-231.

Luarn, P., \& Lin, H. H. (2003). A customer loyalty model for Eservice context. Journal of Electronic Commerce Research, 4, 156-167.

Lynch, P. D., Kent, R. J., \& Srinivasan, S. S. (2001). The global internet shopper: Evidence from shopping tasks in twelve countries. Journal of Advertising Research, 41, 15-23.

McKnight, D. H., Choudhury, V., \& Kacmar, C. (2002). Developing and validating trust measures for e-commerce: An integrative typology. Information Systems Research, 13, 334-359.

Mithas, S., Ramasubbu, N., Krishnan, M. S., \& Fornell, C. (2007). Designing web sites for customer loyalty across business domains: A multilevel analysis. Journal of Management Information Systems, 23, 97-127.

Morgan, R., \& Hunt, S. D. (1994). The commitment-trust theory of relationship marketing. Journal of Marketing, 58, $20-38$.

Nault, R., \& Dexter, A. S. (1995). Added value and pricing with information technology. MIS Quarterly, 19, 449-464.

Oh, S. H., Kim, Y. M., Lee, C.W., Shim, G. Y., Park, M. S., \& Jung, H. S. (2009). Consumer adoption of virtual stores in Korea: Focusing on the role of trust and playfulness. Psychology and Marketing, 26, 652-668.

Oliver, R. L. (1999). Whence consumer loyalty? Journal of Marketing, 63, 33-44.

Oreg, S. (2003). Resistance to change: Developing an individual difference measure. Journal of Applied Psychology, 88, 680-693.

Pavlou, P. A., \& Dimoka, A. (2006). The nature and role of feedback text comments in online market places: Implications for trust building, price premiums, and seller differentiation. Information Systems Research, 17, 392-414.

Pavlou, P. A., \& Fygenson, M. (2006). Understanding and predicting electronic commerce adoption: An extension of the theory of planned behavior. MIS Quarterly, 20, 111-145.

Ping, R. A. Jr. (1993). The effects of satisfaction and structural constraints on retailer exiting, voice, loyalty, opportunism, and neglect. Journal of Retailing, 69, 321-49.

Pritchard, M. P., Havitz, M. E., \& Howard, D. R. (1999). Analyzing the commitment-loyalty link in service contexts. Journal of the Academy of Marketing Science, 27, 333-348.

Reichheld, F. F., \& Sasser, W. E. Jr. (1990). Zero defections: Quality comes to services. Harvard Business Review, 68, 105-111.

Reichheld, F. F., \& Schefter, P. (2000). E-loyalty. Harvard Business Review, 78, 105-113.

Samuelson, W., \& Zeckhauser, R. (1988). Status quo bias in decision making. Journal of Risk and Uncertainty, 1, 7-59.

Singh, J., \& Sirdeshmukh, D. (2000). Agency and trust mechanisms in consumer satisfactions and loyalty judgments. Journal of the Academy of Marketing Science, 28, 150-167.

Smith, M., \& Brynjolfsson, E. (2001). Customer decision making at an Internet shopbot: Brand still matters. The Journal of Industrial Economics, 49, 541-558.
Spreng, R. A., MacKenzie, S. B., \& Olshavsky, R. W. (1996). A re-examination of the determinants of consumer satisfaction. Journal of Marketing, 60, 15-32.

Srinivasan, S. S., Anderson, R., \& Ponnavolu, K. (2002). Customer loyalty in e-commerce: An exploration of its antecedents and consequences. Journal of Retailing, 78, 4150 .

Sung, Y., \& Choi, S. M. (2010). "I won't leave you although you disappoint me": The interplay between satisfaction, investment, and alternatives in determining consumer-brand relationship commitment. Psychology and Marketing, 27, 1050-1073.

Taylor, S. A., \& Hunter, G. (2003). An exploratory investigation into the antecedents of satisfaction, brand attitude, and loyalty within the (B2B) eCRM industry. Journal of Consumer Satisfaction, Dissatisfaction and Complaining Behavior, 16, 19-35.

Tsai, H. T., Huang, H. C., Jaw, Y. L., \& Chen W. K. (2006). Why on-line customers remain with a particular e-retailer: An integrative model and empirical evidence. Psychology and Marketing, 23, 447-464.

Wang, C. Y. (2010). Service quality, perceived value, corporate image, and customer loyalty in the context of varying levels of switching costs. Psychology and Marketing, 27, 252-262.

Yang, Z., \& Peterson, R. T. (2004). Customer perceived value, satisfaction, and loyalty: The role of switching costs. Psychology and Marketing, 21, 799-822.

Correspondence regarding this article should be sent to: HeeWoong Kim, Professor, Yonsei University, 262 Seongsanno, Seodaemun-gu, Seoul 120-749, Korea (kimhw@yonsei.ac.kr)

\section{APPENDIX}

\section{Measurement Instrument}

\begin{tabular}{|c|c|c|}
\hline Construct & Item & Wording \\
\hline \multirow[t]{3}{*}{$\begin{array}{l}\text { Relative } \\
\text { attractive- } \\
\text { ness } \\
\text { (REL) }\end{array}$} & REL1 & $\begin{array}{l}\text { Compared to shopping at } \\
\text { other online bookstores, } \\
\text { Internet shopping at this } \\
\text { store would be more } \\
\text { advantageous to me. }\end{array}$ \\
\hline & REL2 & $\begin{array}{l}\text { Compared to shopping at } \\
\text { other online bookstores, } \\
\text { Internet shopping at this } \\
\text { store would be more } \\
\text { appealing to me. }\end{array}$ \\
\hline & REL3 & $\begin{array}{l}\text { Overall, it would be better } \\
\text { for me to shop from this } \\
\text { store than other online } \\
\text { bookstores. }\end{array}$ \\
\hline \multirow[t]{2}{*}{$\begin{array}{l}\text { Switching } \\
\text { Costs } \\
\text { (SWC) }\end{array}$} & SWC1 & $\begin{array}{l}\text { It would take a lot of time } \\
\text { and effort to switch my } \\
\text { shopping activities here to } \\
\text { another online bookstore. }\end{array}$ \\
\hline & SWC2 & $\begin{array}{l}\text { It would be a hassle for me to } \\
\text { switch my shopping } \\
\text { activities here to another } \\
\text { online bookstore. }\end{array}$ \\
\hline
\end{tabular}


APPENDIX,

Continued

\begin{tabular}{|c|c|c|}
\hline Construct & Item & Wording \\
\hline & SWC3 & $\begin{array}{l}\text { A lot of time and effort have } \\
\text { gone into developing } \\
\text { relationship with this } \\
\text { store. }\end{array}$ \\
\hline & SWC4 & $\begin{array}{l}\text { All things considered, I } \\
\text { would lose a lot if I were to } \\
\text { switch my shopping } \\
\text { activities here to another } \\
\text { online bookstore. }\end{array}$ \\
\hline \multirow[t]{3}{*}{ Trust (TRS) } & TRS1 & $\begin{array}{l}\text { This store keeps its promises } \\
\text { and commitment. }\end{array}$ \\
\hline & TRS2 & $\begin{array}{l}\text { This store cares about its } \\
\text { customers. }\end{array}$ \\
\hline & TRS3 & $\begin{array}{l}\text { This store is capable of doing } \\
\text { its job. }\end{array}$ \\
\hline \multirow[t]{4}{*}{$\begin{array}{l}\text { Satisfaction } \\
\quad(\mathrm{SAT})\end{array}$} & & $\begin{array}{l}\text { I am } \ldots \text { with my } \\
\text { transaction with this store. }\end{array}$ \\
\hline & SAT1 & Unsatisfied ... satisfied. \\
\hline & SAT2 & Frustrated ... contented. \\
\hline & SAT3 & Annoyed ... pleased. \\
\hline \multirow{3}{*}{$\begin{array}{l}\text { Customer } \\
\text { Resistance } \\
\text { to Change } \\
\text { (CRC) }\end{array}$} & CRC1 & $\begin{array}{l}\text { I would not willingly change } \\
\text { my preference to buy } \\
\text { books online at this store. }\end{array}$ \\
\hline & CRC2 & $\begin{array}{l}\text { I would not substitute this } \\
\text { store with another online } \\
\text { store for my book } \\
\text { purchases. }\end{array}$ \\
\hline & CRC3 & $\begin{array}{l}\text { Even if my close friends were } \\
\text { to recommend another } \\
\text { online store, I would not } \\
\text { change my preference for } \\
\text { purchasing books at this } \\
\text { store. }\end{array}$ \\
\hline \multirow[t]{3}{*}{$\begin{array}{l}\text { Willingness } \\
\text { to pay } \\
\text { more } \\
\text { (WPM) }\end{array}$} & WPM1 & $\begin{array}{l}\text { Would you pay the current } \\
\text { prices at this store if other } \\
\text { online bookstores lower } \\
\text { their prices to a level } \\
\text { slightly below those at this } \\
\text { store? }\end{array}$ \\
\hline & WPM2 & $\begin{array}{l}\text { Would you pay the prices at } \\
\text { this store if they are } \\
\text { increased slightly? }\end{array}$ \\
\hline & WPM3 & $\begin{array}{l}\text { Would you pay the prices at } \\
\text { this store if this store } \\
\text { raises its prices slightly } \\
\text { above those at other online } \\
\text { bookstores? }\end{array}$ \\
\hline
\end{tabular}

